\title{
Assessment of Customers' Perception towards Service Delivery among Public Service Organizations in Dire Dawa Administration
}

\author{
Muluken Mengste \\ Senior expert and Researcher, Dire Dawa Management and Kaizen Institute \\ Zewdu Teshome \\ Senior expert and Researcher, Dire Dawa Management and Kaizen Institute \\ Behailu Belete \\ Senior expert and Researcher, Dire Dawa Management and Kaizen Institute \\ Girma Gizaw \\ Senior expert and Researcher, Dire Dawa Management and Kaizen Institute \\ Aschalew Mulugeta \\ Ass. Professor, Advisor, Dire Dawa University
}

\section{The research is financed by Dire Dawa Administration}

\section{Abstract}

The issue of service delivery is becoming a global concern that demands continuous reform to fit the turbulent environment and changing customer needs. The purpose of this study was therefore to assess customer satisfaction on service delivery of selected public service organizations in Dire Dawa city Administration. The study employed the cross-sectional field survey method since relevant data were collected via at one point in time at public service organizations by distributing questionnaires to customers. A sample of 870 customers and 206 employees were randomly selected as study respondents in which In combination of a mixed research design was employed to quench the objectives of the study. Descriptive statistics, Spearman's correlation, mean values, frequency distribution and percentages were used to analyze the responses of respondents. The results of the study indicated that the five service delivery dimensions and customer satisfaction were positively correlated; the general level of customer satisfaction and the service delivery dimensions were moderate. The major challenges in service delivery such as lack of service mentality and deterioration of employees' motivation, prevalence of corruption and rent seeking activities and behavior, absence of regular consultation with customers and stakeholders, lack of cooperation and integration among stakeholders, insufficient skilled man power, shortages of equipment and machineries, inefficient and inappropriate grievance handling systems, lack of revision of existing rules and regulations on timely basis, inability/under capacity of the middle managers to monitor and manage employees, and discrepancy between supply and demand were thoroughly identified. Finally, based on the analysis and conclusions, possible recommendations were suggested for alleviating the major challenges of service delivery processes in the study area.

Key Terms: Customer Satisfaction, Dire Dawa Administration, Public Service Organizations, Service Delivery DOI: $10.7176 / \mathrm{PPAR} / 10-10-05$

Publication date:October $31^{\text {st }} 2020$

\section{INTRODUCTION}

\subsection{Background of the study}

The issue of service delivery is becoming a global concern that demands continuous reform to fit the dynamic environment and changing customer needs. Efficient and effective services delivery is now a prominent agenda of most countries including Ethiopia. The Ethiopian People's Revolutionary Democratic Front (EPRDF) has been taking different reform measures in the political, economic and social spheres. It has also taken comprehensive measures to restructure the civil service, one of which is the civil service reform. In the early 1990s, the government launched Civil Service Reform Program (CSRP). The reform has included five sub-programs, one of which is the service delivery and quality of service sub-program. The program is under the responsibility of the Office of the Prime Minister and is designed to improve the quality of service provided by public sector employees and includes the establishment of a complaint-handling mechanism. The program would have made civil service institutions follow an appropriate and improved system of service delivery so as to give service to the public in an effective, efficient, transparent and impartial manner. The employees of the civil service institutions have the responsibility and obligation to provide quality service to the public fairly, equitably, honestly, efficiently and effectively (Paulos, 2001).

Most of the civil service institutions in our country lack appropriate customer service policies, the institutional 
capacity and resources to cope with customer service challenges. Despite the efforts made by the Ethiopian government, the implementation of the civil service reform regarding the service delivery has faced many challenges. According to Yosef (2011) and Zerihun (2014), lack of cooperation from staff (since the reform is viewed as downsizing the work force), inadequate staff training and development, lack of enthusiasms and interest, lack of top management support, lack of motivation and communication of the vision and inadequate commitment to reform, lack of visionary leadership, and unclear accountability relationship between public service providers were the main challenges. These challenges may affect customers' satisfaction.

Currently, customer satisfaction has become a subject of great interest to organizations and researchers. Customer satisfaction is the individual's perception of the performance of the-product or service in relation to his or her expectations. The concept of customer satisfaction is a function of customer expectations. A customer whose experience falls below expectations will be dissatisfied. And customers whose expectations are exceeded will be very satisfied or delighted (Schiffman and Kanuk, 2005). Recently, the government of Ethiopia has started introducing new ways of doing business under the civil service reform program to enhance the institutional capacity of the public service organizations. Following this initiative, nearly all public service organizations in Dire Dawa administration have implemented the reform program using Business Process Reengineering (BPR), Balanced Score Card (BSC), and other reform management tools, and complaint management system to enhance the service quality by reducing the negative effects of customer dissatisfaction. The city administration has been implementing the Business Process Reengineering for the last seven years. Besides, the public service organizations are attempting to provide services in accordance with the perceived standards set in their respective citizens' charter documents. However, it is observed that lack of customer satisfaction is one of the most important problems. The demand for effective and efficient delivery of services requires fundamental change involving both institutional and cultural changes. Hence, measuring the level of satisfaction provides an indication of how successful organizations are at providing services, and is taken as effective outcome measure. This study therefore aims to assess customer satisfaction on the service delivery of public service organizations in Dire Dawa Administration.

\subsection{Statement of the problem}

The problem of this research is induced by the need to empirically measure customer satisfaction on service delivery of selected public service organizations in Dire Dawa Administration. According to Benjamin (2012), public service organizations exist to provide services to the citizens, the private sector and other institutions. It is a well-known fact that service delivery by public service organizations is inundated with several challenges. Mohammed et al (2010), sited in Benjamin (2012), stated that public service organizations agree that customer service is one of the most important vital factors that contribute to the establishment of reputation and credibility among the public. They also argued that the public- complaint of long queues, poor service delivery and insufficient physical facilities might affect the image and level of service quality in the public sector Despite the efforts made by the government of Ethiopian, the service delivery and grievance handling system of most of the public service organizations are not in a position to fully satisfy large number of customers. Problems have been observed in delivering services to the public in a manner that is satisfying customers. According to Yoseph (2011), one of the major problems in the civil service institutions of Ethiopia was low service delivery systems which could lead to low efficiency of service delivery.

Several researches have been conducted on the subject matter; however, most of them were focusing on private sectors such as insurance, hotel, bank and the like (Akalu, 2015; Ibraheem and Chinonso, 2015; Jayaraman et al, 2010). Few are studied on public service organizations like, Social Security Agency and Document Authentication and Registration Office, Customer Satisfaction in Land Delivery Service a case study of Bishoftu Town Administration, Service Delivery and Customer Satisfaction: the Case of Ethiopian Electric Power Corporation Eastern Addis Ababa Region Customer Service Centers, (Desta, 2008; Mohammed, 2008; Zeritu, 2010).

Moreover, as far as the researchers' knowledge is concerned, there is no study so far conducted to investigate the state of customer satisfaction on service delivery of public service organizations in Dire Dawa Administration. Therefore, this research was conducted to assess customer satisfaction perception towards service delivery in selected public service organizations in Dire Dawa city Administration.

\subsection{Objectives of the Study}

The main objective of the study was customer perception towards service delivery in selected public service organizations of Dire Dawa Administration.

\section{Specific Objectives of the Study}

The study also tried to achieve the following specific objectives:

1. To measure the level of customer satisfaction of selected public service organizations in Dire Dawa city Administration 
2. To assess the service delivery process of public service organizations in terms of service delivery dimension (Assurance, Reliability, Tangibility, Empathy, and Responsiveness)

3. To examine the relationship between service delivery dimension and customer satisfaction.

4. To find out major problems that exists in the service delivery process of public service organizations

\section{Review of Related Literature Review}

Public service delivery is the most important element of NPM driven PSRs. Akalu (2015) stated that among the factors that caused the first and second generation of reforms in developing countries to fail was the lack of emphasis on public service delivery. Yonatan (2010) also stated the major failure of the first generation reform of 1980s and 1990s was to focus merely on reforms in the organization rather than on public service delivery, due to the pressure of crisis and structural adjustments. The third generation reforms emphasized on public service delivery based on the lessons learnt from the previous reforms. PSRs that fail to emphasize on public service delivery are unlikely to be successful. The meaning and related concepts of public services are discussed briefly as follows (Mintesnot, 2016). Public services is a term usually employed to mean services provided by the government to the citizens either directly (through the public sector) or indirectly by financing the private provision of the services, and it is associated with a social consensus (usually expressed through democratic elections) that certain services should be available to all, regardless of their income (Rida et al., 2012). According to Zertu (2010), for service organization or service provider, satisfying or fulfilling the expectation of its customer is one of the major goals. It is stated in the article of Joan and Joseph, (2002) that for service providers, their main task is to reduce the mismatch or gap between what the organization planned to provide and what the end users (customers) are expecting to benefit from the service they have been offered.

The SERVQUAL model was first introduced by Parasuraman and colleagues in 1985 in the United States. Since its inception SERVQUAL has become a popular method for measuring service quality (Saunders et al., 2009). It involves measuring both customer perceptions and expectations of service along key service quality dimensions. It was concluded that SERVQUAL is the best model to measure service quality in the public service (Tessa et al., 2011). Moreover, the SERQUAL (Parasuraman, 1988) approach has been the most popular method for choosing because it is quite complete measure for all service organizations. Therefore, this research bears on these conclusions and adopts SERVQUAL model to assess the customer satisfaction on service delivery of public service organizations in Dire Dawa Administration.

The study conducted by parasuraman et al, (1985) resenting the five-dimensions of SERVQUAL on quality of service provided by the clinic at the University of Houston Health Center. Patients were found to be generally dissatisfied with the five dimensions of SERVQUAL. The highest dissatisfaction was felt with assurance. On the other hand, tangibles and empathy exhibited the lowest levels of dissatisfaction. Using the SERVQUAL approach, Minazzi (2008) carried out a study to assess customer satisfaction within the public sector across a range of Scottish Councils services. In the library service, the analysis of gap scores revealed that tangibles and reliability had negative gaps which indicate that customer expectations were not met. On the other hand, responsiveness and assurance were positive implying that customer expectations were actually exceeded by the service provided. The research conducted by Rida, et al (2012), on the influence of service quality and corporate image on customer satisfaction among university students in Kenya revealed four dimensions of service quality as human elements reliability, service blue print, human element responsiveness and non-human elements. The four dimensions had Eigen values greater 1 and Cronbach's alpha greater than 0.700 , they were considered adequate and reliable in explaining variations in customer satisfaction. Human elements reliability with a Cronbach's alpha of 0.931 and corporate image with Cronbach's alpha of 0.909 , had the greatest influence on customer satisfaction. The study established the existence of a significant difference in the dimensions of service quality that influence customer satisfaction between public and private university students along the four service quality dimensions. A statistically significant relationship was established between service quality and customer satisfaction. The relationship between service quality and corporate image was statistically significant. Further findings revealed that a statistically significant relationship existed between corporate image and customer satisfaction.

\section{Methods and Materials}

\subsection{Research Design and strategy}

The study employed the cross-sectional field survey method to assess the level of customer satisfaction on service delivery of public service organizations based on respondents' attitudes. In cross-sectional field survey method, relevant data were collected at one point in time at public service organizations by distributing questionnaires to customers. In this method, independent and dependent variables were measured at the same point in time using a single questionnaire. Along with the cross sectional nature of this study, the study employed descriptive research method to analyze the data collected from customers. This method enabled the researchers to describe the existing situation under study. It was used to describe the service quality dimensions that would lead to customer satisfaction. It was also used for detail description of the findings displayed in tables and charts as well as for 
developing inferences on the level of customer satisfaction on service delivery of public service organizations. Moreover, the study used explanatory study design, to explain, understand and control the relationship between variables.

In order to acquire the best results, the researchers used the way of triangulation. A combination of both qualitative and quantitative method was employed in this research. The researchers believed that using these two methods simultaneously enabled them to tackle the research problem under study. Mixing different methods can strengthen a study; it would be a great advantage when the findings of one were corroborated by the other. Therefore, quantitative approaches have been used for the data collected from respondents through questionnaire. To provide a more complete picture of evaluation, the study also applied qualitative approaches for the data gathered from interviews and secondary sources.

\subsection{Sampling Technique and Sample Size}

The researchers selected seven public service institutions using purposive sampling technique. These institutions were: Revenue Authority, Water and Sewage Authority, Land Development and Management Bureau, Dilchora Referral Hospital, Dire Dawa First Instance Court, Ethiopian Electric Utility, and Kebele 06 Administration. The selection of these institutions was on the basis of some criteria like high number of customers, large budget allocation, and their importance in the social and economic setting of the city administration. Besides, Kebele 06 Administration was selected because it was the one to implement reform programs for the first time among others. The target population of the study was the total number of customers who have accessed services in the selected seven public service institutions from July 2015 to 2016 in Dire Dawa Administration. The total population of these customers was about 27,458 . This figure was computed by summing up the estimated average number of monthly customers of the selected public service institutions, except for Dilchora Referral Hospital whose estimated average number of customers was taken on a daily basis for sample size determination. The other target population was the employees of the selected public service institutions. These were experts or officers who have direct or frequent contact with the customers. The total population of these employees was 529 . The choice of past customers/clients was informed by the fact that satisfaction with the service delivery can properly be assessed after one has fully or to a greater extent experienced the service. In effect, care was taken not to select very old or past clients as memories of their experiences might have been faded.

The total population of customers and employees from the selected public service institutions were 27,458 and 529 respectively. A sample of 870 customers and 206 employees were taken based on the minimum precision (0.01). The study used systematic random sampling methods to select customer and employee respondents. Moreover, Purposive sampling technique was used to select heads of the institutions and/or core process owners for interview. They were those who sometimes interacted with the customers and as such had some in-depth knowledge and better understanding about the concerns and needs of the customers. The total population of these informants was seven, and all of them were selected for interviewing as the population was not large.

\subsection{Method of Data Collection}

Data for this study were collected through Document review, Structured Questionnaires, Semi-structured interviews. Documentation involves collecting information and data from existing surveys, reports, journals and any relevant publications. The Structured Questionnaire which was consisting of 26 items was primarily developed in Amharic language version to make it easily understandable by respondents and then converted into English language for analysis purpose.

Both open ended and close ended questions were designed to collect quantitative data. The questionnaire had two major parts. The first part was about the demographic characteristics of respondents. The second part was designed to measure the service delivery processes of the selected public service organizations by using the SERVQUAL model as proposed by Parasuraman et al (1988), comprising five components of service quality. The components were Empathy, Responsiveness, Assurance, Tangibility, and Reliability.The researchers used a fivepoint Likert scales, representing a range of attitudes from strongly disagree (1) to strongly agree (5), to measure the variables. The dimensions of service quality delivery (independent variables) were measured using the SERVQUAL model, whereas the customer satisfaction (dependent variables) were measured using a single scale item which comprised a range of scales from very low (1) to very high (5). Semi-structured interviews were also conducted using interview guide with the selected key informants to obtain more detailed information, in such a way that the researchers probed by raising some related questions for further explanation. This was intended to get further information which could answer the research questions.

\subsection{Data Analysis and Presentation}

Descriptive statistics, Spearman's correlation, mean values, frequency distribution and percentages were used to analyze the responses of respondents. Presentation devices such as tables, graphs, and charts were also used to analyze and present the results. Qualitative analysis was done by narrating the views and themes based on the 
research objectives, research questions and the issues discussed.

\section{Results and Discussion}

\subsection{Level of Satisfaction}

\subsubsection{Level of Customer Satisfaction}

Customer satisfaction is the degree to which customer perceives that an individual, firm or organization has effectively provided a product or service that meets the customer's needs in the context in which the customer is aware of and / or using the product or service (Cengiz, 2010). Accordingly, all 831 customer respondents were asked to assess their overall level of satisfaction with the ongoing services in the selected public service organizations in terms of showing their levels of agreement and disagreement using 5 category Likert-scale ( 1 very low to 5 very high). The following Pie Chart illustrated the responses of sample respondents.

\section{Figure 4.1.: Overall Satisfaction Score of Customers}

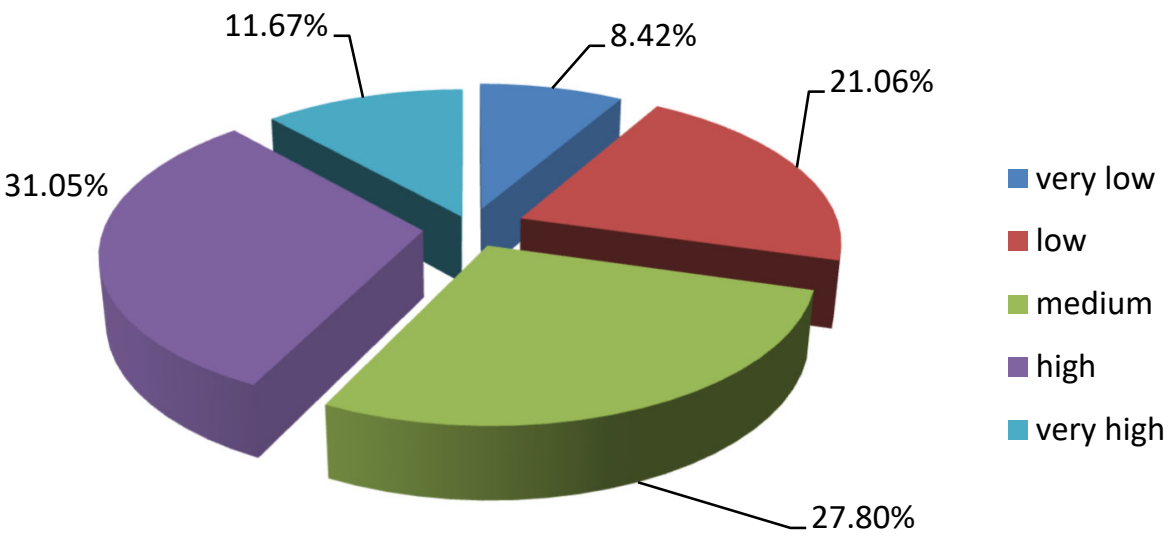

Figure 4.1 presented data about overall satisfaction levels of customers with the services they get from the selected public service organizations of Dire Dawa Administration. As it can be seen from responses of respondents, $8.42 \%, 21.06 \%, 27.80 \%, 31.05 \%$ and $11.67 \%$ respondents expressed their level of satisfaction as very low, low, medium, high and very high respectively. This implies that, majority $(70 \%)$ of sample respondents had moderate and above satisfaction level with the service delivery statuses of the selected public service organizations. In contrast, about $30 \%$ of respondents reported low level of satisfaction.

\subsubsection{Level of Employee Satisfaction}

Similarly, Employees responses about overall satisfaction on service delivery of their respective institution were presented in table 4.1 below

Table 4.1: Employee`s perception on Overall satisfaction level

\begin{tabular}{|l|r|r|}
\hline Item & Frequency & Valid Percent \\
\hline Low & 23 & 12.8 \\
\hline Medium & 45 & 25.1 \\
\hline High & 85 & 47.5 \\
\hline very high & 26 & 14.5 \\
\hline Total & 179 & 100.0 \\
\hline
\end{tabular}

As indicated in table 4.1 above, Employees rated the overall satisfaction level on service delivery as very low $(0 \%)$, low (12.8\%), medium (25.1\%), high (47.5\%) and very high (14.5\%). This implies that, majority $(62 \%)$ of respondents had rated satisfaction level of the service delivery as high.Only about $12.8 \%$ of respondents reported low level of satisfaction.

Table 4.2: General Customer Satisfaction by Service delivery Dimensions

\begin{tabular}{|l|r|r|r|}
\hline \multicolumn{1}{|c|}{ Item } & Mean & Std. Deviation & N \\
\hline General Satisfaction & 3.16 & 1.14 & 824 \\
\hline Empathy & 3.63 & 1.21 & 824 \\
\hline Responsiveness & 3.24 & 1.32 & 824 \\
\hline Assurance & 3.49 & 1.17 & 824 \\
\hline Tangibility & 3.37 & 1.17 & 824 \\
\hline Reliability & 3.22 & 1.27 & 824 \\
\hline
\end{tabular}

To support the above results, mean scores (where scores approached to 1 indicates the worst (minimum) score 
while scores approached to 5 shows best (maximum) satisfaction level) were computed. Accordingly, the mean scores of average satisfaction computed from the five dimensions-Empathy, Responsiveness, Assurance, Tangibility, and Reliability- and general satisfaction were 3.42 and 3.16 respectively. The average satisfaction has greater mean score than that of the overall satisfaction. These results indicated that mean score was better when it was asked in a disaggregated manner than asking in a question directly.

In conclusion, the general customer satisfaction mean scores in the administration for all dimensions showed moderate. More specifically, Empathy, Responsiveness, Assurance, Tangibility, and Reliability accounted for average scores of 3.63, 3.24, 3.49, 3.37, and 3.22 respectively.

Table 4.3: General Customer Satisfaction Level by Organizations

\begin{tabular}{|c|c|c|c|c|c|c|c|c|}
\hline \multirow[b]{2}{*}{$\begin{array}{l}\text { Name of the } \\
\text { Institution }\end{array}$} & \multicolumn{5}{|c|}{ General/Overall Satisfaction (\%) } & \multicolumn{2}{|c|}{ Mean Score } & \multirow[b]{2}{*}{ Total } \\
\hline & $\begin{array}{l}\text { very } \\
\text { low }\end{array}$ & low & med & high & $\begin{array}{l}\text { very } \\
\text { high }\end{array}$ & $\begin{array}{l}\text { Gen. Sat } \\
\text { mean }\end{array}$ & $\begin{array}{l}\text { Gen. Sat } \\
\text { Std. Dev }\end{array}$ & \\
\hline Land & 26 & 25 & 14 & 26 & 9 & 2.65 & 1.34 & 84 \\
\hline Revenue & 6 & 14 & 21 & 38 & 21 & 3.53 & 1.15 & 109 \\
\hline Water & 5 & 13 & 27 & 38 & 17 & 3.50 & 1.07 & 150 \\
\hline Court & 5 & 28 & 24 & 34 & 9 & 3.14 & 1.08 & 100 \\
\hline Dilchora & 0 & 16 & 37 & 43 & 4 & 3.34 & 0.79 & 148 \\
\hline Kebele06 & 0 & 4 & 27 & 37 & 32 & 3.98 & 0.87 & 49 \\
\hline EEU & 15 & 34 & 33 & 13 & 5 & 2.58 & 1.05 & 191 \\
\hline & & & & & & & Total & 831 \\
\hline
\end{tabular}

Source: Field Survey, 2016

The table 4.6 above shows that the disaggregated customer satisfaction scores for each selected organization. Out of 84 respondents of Land Development and Management Bureau Overall Customer Satisfaction Level scores $26 \%, 25 \%, 14 \%, 26 \%$ and $9 \%$ are very low, low, medium, high and very high respectively. This implies $51 \%$ of the respondents have below moderate satisfaction level. Similarly, out of 191 respondents of EEU`s Overall Customer Satisfaction Level scores 15\%, 34\%, 33\%, 13\% and 5\% were responded as very low, low, medium, high and very high respectively. This implies $49 \%$ of the respondents have below moderate satisfaction level, whereas $51 \%$ of the respondents have moderate and above satisfaction level with the services they get from a given organization.

This result is supported by the calculated mean scores of both organizations, namely Land Development and Management Bureau and EEU, with mean scores of 2.76 and 2.96 respectively. This implies that both organizations have below moderate satisfaction level.

On the other hand, the remaining organizations such as Revenue Authority, Water and Sewerage Authority, First Instance Court, Dilchora Hospital and Kebele 06 Administration have average mean scores of 3.84, 3.79, $3.39,3.52$ and 4.26 respectively. This shows that the satisfaction level of these organizations were moderate and above.

Table 4.4: General Employees Satisfaction Level by Organizations

\begin{tabular}{|c|c|c|c|c|c|c|c|c|}
\hline \multirow{2}{*}{$\begin{array}{l}\text { Name of the } \\
\text { Institution }\end{array}$} & \multicolumn{5}{|c|}{ General/Overall Satisfaction (\%) } & \multicolumn{2}{|c|}{ Mean Score } & \multirow[b]{2}{*}{ Total } \\
\hline & $\begin{array}{l}\text { very } \\
\text { low }\end{array}$ & low & med & high & $\begin{array}{l}\text { very } \\
\text { high }\end{array}$ & $\begin{array}{c}\text { Gen. Sat } \\
\text { mean }\end{array}$ & $\begin{array}{l}\text { Gen. Sat } \\
\text { Std. Dev }\end{array}$ & \\
\hline Land & 0 & 7.14 & 35.71 & 57.14 & 0 & 3.50 & 0.65 & 15 \\
\hline Revenue & 0 & 0 & 10.71 & 57.14 & 32.14 & 4.21 & 0.63 & 29 \\
\hline Water & 0 & 13.3 & 13.3 & 66.67 & 6.67 & 3.67 & 0.80 & 33 \\
\hline Court & 0 & 18.18 & 27.27 & 27.27 & 27.27 & 3.64 & 1.12 & 11 \\
\hline Dilchora & 0 & 20.97 & 37.10 & 35.48 & 6.45 & 3.27 & 0.87 & 68 \\
\hline Kebele06 & 0 & 0 & 8.33 & 58.33 & 33.33 & 4.25 & 0.62 & 12 \\
\hline EEU & 0 & 23.08 & 30.77 & 38.46 & 7.69 & 3.64 & 0.95 & 22 \\
\hline
\end{tabular}

Table 4.4 above showed that employees responses about general satisfaction level on service delivery of the selected institutions were 3.50, 4.21, 3.67, 3.64, 3.27, 4.25 and 3.64 for Land Development and Management Bureau, Revenue Authority, Water and Sewerage Authority, First Instance Court, Dilchora Hospital, Kebele 06 Administration and EEU respectively. This implies that the responses of employees in all the selected institutions indicated that the general level of customer satisfaction on service delivery were moderate and above unlike that of customers. Finally, reliability includes keeping promise, free from corruption and rent seeking, accessibility of service, provision of services as per standards and fair service provision.

The aggregated mean scores of service delivery measurement dimensions of selected public service organizations in Dire Dawa Administration. Accordingly, Empathy has the highest mean score of 3.54, followed by Assurance, Tangibility and Responsiveness with mean scores of 3.44, 3.32 and 3.21 respectively. The least 
important dimension according to the finding is Reliability with a mean score of 3.19. These findings indicate that the composite mean scores are all less than 4 for each service measurement dimension and yet the maximum possible score is 5 . The mean composite scores are above average but less than the mean maximum score. The findings of the study indicate that currently the service delivery standard as evaluated by the customers found to be moderate. The result also indicated further that customers viewed empathy to play a key role in determining the standards of service received whereas Reliability plays a least role. On the other hand, the employees' responses on the average mean score of service delivery dimensions for the selected organizations. Empathy has still the highest mean score of 4.28 and assurance with a mean score of 4.20 , followed by responsiveness, reliability, and tangibility with mean scores of $3.9,3.83$, and 3.67 respectively.

\subsection{Major Challenges that prevailed in the Service Delivery Process of Public Service Organizations}

The major challenges in service delivery of Dire Dawa Administration obtained from customers, employees, KII, and content analysis were:

- Lack of skilled and experienced leadership, instability of officials, inability to lead and make decisions strategically, frequent meetings on working hours, lack of timely response and keeping appointments to provide services, inconsistent follow up and monitoring, absence of regular consultation with customers and stakeholders, prevalence of corruption and rent seeking activities and behavior, turnover, inadequate technical capacity and skills, lack of motivation and service mentality, unethical behavior, lack of empowerment and problem solving capacity were the major challenges.

- Lack of customer oriented services, ineffective automation, absence of timely revision of rules and regulations; frequent interruption of networks and electric power, lack of cooperation and integration among stakeholders, inefficient and inappropriate grievance handling systems in place.

- Lack of equipments and machineries, inaccessibility of selling registration machines, inadequate medical facilities, inadequate supply and dalliance of Meters, Fuses and Poles.

- Inappropriate referral system and overflow of customers out of catchment area, inadequate production and selling premises for micro and small enterprises, absence of decentralization of land services at kebele level, mismatch between demand and supply in water, health and electric services, as well as the structural and local development plans were among the major challenges.

- The pre-determined service delivery procedure, standards and change management tools lack working and implementation manuals; and different formats to put them into effect. In addition, absence of conducting customer satisfaction surveys scientifically.

\subsection{Correlation Analysis Results}

Researchers calculated Spearman's Correlation to check whether the aggregate levels of satisfaction are significantly correlated with the five dimensions of service delivery scores. As it can be presented in table 4.5 the correlation results indicated that there is significant relationship among all variables. In other words, the result shows that there is significant and positive relationship between customer satisfaction and the five service delivery dimensions (Empathy, Responsiveness, Assurance, Tangibility and Reliability). From this, one can conclude that service delivery dimensions are positively correlated with customer satisfaction, implying that they are dominant components/attributes to measure customer satisfaction.

Table 4.5: The Spearman's correlation coefficients of the service delivery dimensions and general customer satisfaction

\begin{tabular}{|c|c|c|c|c|c|c|c|}
\hline \multicolumn{8}{|c|}{ Correlations } \\
\hline \multicolumn{2}{|c|}{ Model } & General & Empathy & Responsiveness & Assurance & Tangibility & Reliability \\
\hline $\begin{array}{l}\text { General } \\
\text { Satisfaction }\end{array}$ & \multirow{6}{*}{$\begin{array}{l}\text { Correlation } \\
\text { Coefficient }\end{array}$} & 1.000 & $.688^{* *}$ & $.727^{* *}$ & $.706^{* *}$ & $.690^{* *}$ & $.768^{* *}$ \\
\hline Empathy & & $.688^{* *}$ & 1.000 & $.728^{* *}$ & $.715^{* *}$ & $.654^{* *}$ & $.697^{* *}$ \\
\hline Responsiveness & & $.727^{* *}$ & $.728^{* *}$ & 1.000 & $.750^{* *}$ & $.701^{* *}$ & $.786^{* *}$ \\
\hline Assurance & & $.706^{* *}$ & $.715^{* *}$ & $.750^{* *}$ & 1.000 & $.715^{* *}$ & $.779^{* *}$ \\
\hline Tangibility & & $.690^{* *}$ & $.654^{* *}$ & $.701^{* *}$ & $.715^{* *}$ & 1.000 & $.774^{* *}$ \\
\hline Reliability & & $.768^{* *}$ & $.697^{* *}$ & $.786^{* *}$ & $.779^{* *}$ & $.774^{* *}$ & 1.000 \\
\hline
\end{tabular}

\section{Conclusions and Recommendations}

The general objective of the study was to assess the customer satisfaction on service delivery of public organizations in Dire Dawa Administration. The study used the five service delivery elements assurance, reliability; 
tangibility, empathy, and responsiveness to measure customer satisfaction and service delivery. The inferential statistics result indicated that the service delivery dimensions and customer satisfaction have positive correlation, depicting that the service delivery dimensions were found appropriate attributes for measuring customer satisfaction.

The study concluded that the quantitative results of the general level of customer satisfaction and the service delivery dimensions were moderate. However, the position deduced from qualitative result depicted that there were major challenges in service delivery such as lack of skilled and experienced leadership, inability to lead and make decisions strategically, inconsistent follow up and monitoring, absence of regular consultation with customers and stakeholders, prevalence of corruption and rent seeking activities and behavior, lack of motivation and service mentality, ineffective automation, absence of timely revision of rules and regulations; lack of cooperation and integration among stakeholders, inefficient and inappropriate grievance handling systems, mismatch between demand and supply in water, health and electric services, and absence of conducting customer satisfaction surveys scientifically were found to be the major challenges in service delivery of the administration. So, public service institutions should give due attention to the following issues:

As observed from the results of study, the general level of customer satisfaction in the administration is moderate, and this means higher officials should give due emphasis for and work on the service delivery dimensions to achieve maximum level of satisfaction. Furthermore, the disaggregated results on the level of customer satisfaction particularly in Land Development and Management, and Ethiopian Electric Utility are found below average, and hence the officials of these organizations should exert more efforts to enhance their customer satisfaction levels by establishing customer service representative units which are responsible for conducting periodic customer satisfaction surveys, monitoring the service delivery processes whether services are rendered as per the set standards or not, handling customers' complaints, analyzing customers' suggestions and opinions and thereby generating alternative solutions; by empowering employees through the arrangement of various training programs on customer handling, code of conduct, and technical skills.

As indicated in the result, the mean score value are moderate for all service delivery dimensions but with the lowest value for responsiveness and reliability dimension. Thus in the administration the service delivery process requires great attention from administration and organizational top officials, and it will need to establish a customer handling units in each organization that facilitates customers service delivery in accordance with the needs of customers with particular responsibility

The inferential statistics results of the study showed that the five service delivery dimensions and customer satisfaction are positively correlated. This means the officials of the organizations should focus and work hard on the attributes of these service delivery dimensions to enhance their respective customer satisfaction.

The Administration should strive to solve the major bottlenecks in service delivery of each particular organization that are identified in the study by giving priority based on the urgency of the problem and its impact on customer satisfaction especially problems related to input and staffing appropriate employees.

The Administration should design and implement continuous human resource development programs like short and middle term training programs; rewarding system, strengthen the implementation of code of conduct, anti-corruption and rent seeking mitigation strategies to alleviate the prevailing corruption and rent seeking practices, unethical behavior; and to improve service mentality.

The Administration should appoint capable and well qualified leaders at all levels by considering the specific nature of the organizations, and should set a minimum requirement for appointing leaders and organize gap based consistent capacity building programs.

The Administration should design and implement an intentional and collective approach to organize and lead all service delivery system to address public problems through building shared knowledge, designing communicable and innovative solutions, and forging consequential change.

\section{References}

Ahmad M. Zamil, 2011. Role of Measuring Customer Satisfaction in Improving the Performance in the Public Sector Organization. King Saud University, Kingdom of Saudi Arabia. Journal of Business Studies Quarterly 2011, Vol. 2, No. 3, pp. 32-41. ISSN 2152-1034

AkaluAwlachew, 2015. The Effect of Service Quality on Customer Satisfaction In Selected Insurance Companies In Addis Ababa. Master's degree thesis. Addiss Ababa University, Addis Ababa, Ethiopia.

Amin, Samia and NazmulChaudhury, 2008. “An Introduction to Methodologies for Measuring Service Delivery in Education" in Amin, Samia, Das Jishnu and Marcus Goldstein (editors) Are you Being Served? New Tools for Measuring Service Delivery, The World Bank, Washington, D.C.

Benjamin,Amanfi, 2012.Service Quality and Customer Satisfaction in Public Sector Organizations: A Case Study of the Commission on Human Rights and Administrative Justice, Masters of Business Administration,Kwame Nkrumah University.

Benjamin Amanfi, 2012.Service Quality and Customer Satisfaction in Public Sector Organizations: A Case Study 
of the Commission on Human Rights and Administrative Justice, Masters of Business Administration,Kwame Nkrumah University.

Besley, Timothy and MaitreeshGhatac, 2006. "Reforming Service Delivery", Journal of African

BiljanaAngelovaand JusufZekiri, 2011. Measuring Customer Satisfaction with Service Quality Using American Customer Satisfaction. International Journal of Academic Research in Business and Social Sciences. October 2011, Vol. 1, No. 3. ISSN: 2222-6990

Buttle, F., 2005. Customer Relationship Management: concepts and tools. Oxford: Elsevier ButterworthHeinemann.

Chich Jen and I-Ming Mang, 2007. The relationship between service Quality and Customer Satisfaction . Chang Chung University. Taiwan Accessed on June, 2016

Chingang, et al., 2010. Using the SERVQUAL Model to assess Service Quality and Customer Satisfaction. An Empirical study of grocery stores in Umea.Umeå School of Business, Masters Thesis.

Creswell, J.W., 2003. Research design: Qualitative, quantitative, and mixed method approaches, $2^{\text {nd }}$ edition Sage Publication.

Creswell, J.W., 2003. Research design: Qualitative, quantitative, and mixed method approaches, $2^{\text {nd }}$ edition Sage Publication.

Dawkins, P. and ReichheldF., 1990. "Customer as a Competitive Weapon," DirectorsandBoards, 14 (Summer).

Desta Tesfaw, 2008. Public service delivery reform and customer satisfaction: the case of social security agency (ssa) and document authentication and registration office (daro). Master's Degree Thesis. Addis Ababa University. Addis Ababa, Ethiopia.

Douglas, L. \& Connor R., 2003. Attitudes to service quality- the expectation gap, Nutrition \& Food Science, Vol. 33 Number 4, p.165-172.

Dr. Abdel Fattah Mahmoud Al-Azzam, 2015. The Impact of Service Quality Dimensions on Customer Satisfaction: A Field Study of Arab Bank in Irbid City, Jordan. European Journal of Business and Management. ISSN 2222-1905 (Paper) ISSN 2222-2839 (Online), Vol.7, No.15, 2015. Accessed on www.iiste.org

Economies (16): 127-156.

EndalkachewAbebe, 2013. Assessing the impact of Core Banking and service quality on Customer Satisfaction in Commercial Bank of Ethiopia (A case of Bishofftu Branch). Master's Degree Thesis. Hawasa University, Hawasa, Ethiopia.

EnyonamAfiAko-Nai, 2011. Effect of Customer Service on Customer Satisfaction, A Case Study of FidelityBank, Adum, Kumasi. Master's degree thesis. Kwame Nkrumah University of Science and Technology. Accessed on June, 2016

Erkan, Ali Caglar, Ufuk Kaya and ÇağlarKadir, 2014. Service Quality and Customer Satisfaction Relationship: A Research in Erzurum Ataturk University Refectory. American International Journal of Contemporary Research Vol. 4 No. 1; January 2014

Giese, J. L. \& Cote, J. A., 2000. Defining Consumer Satisfaction, Academy of Marketing Science Review, 2000

Grönroos. C., 2000. A service quality model and its market application. Accessed on June, 2016

Gronroos C., 1984.'A Service Quality model and its marketing implications', European Journal of Marketing. $18: 36-44$.

Hayes, B. E., 2008.Measuring Customer Satisfaction: Survey design use and statistical analysis methods.3rd edition.

Hermen Jan Van Ree., 2009. Service Quality Indicators For Business Support Services. Doctor of Philosophy degree Thesis. London University, England.

HM Government, 2007. How to measure customer satisfaction. Improve the experience of customers. Accessed on June, 2016

Israel Berhanu, 2015. Measuring customer satisfaction of ethiopian electric utility. Master`s Degree Thesis. Addis Ababa University, Addis Ababa, Ethiopia.

JayaramanMunusamy, Shankar Chelliah and Hor Wai Mun, 2010. Service Quality Delivery and Its Impact on Customer Satisfaction in the Banking Sector in Malaysia. International Journal of Innovation, Management and Technology, Vol. 1, No. 4, October 2010 ISSN: 2010-0248

Joan L. Giese and Joseph A. Cote, 2002. Defining Consumer Satisfaction. Volume 2000 No. 1 Accessed: http://www.amsreview.org/articles/giese01-2000.pdf

Kindye Essa Mustofa, 2011. Effect of after sale services on customer satisfaction and loyalty in automotive industry of ethiopia. . Master`s Degree Thesis. Addis Ababa University. Addis Ababa, Ethiopia.

Kotler P., Armstrong G., Saunders J. Wong V., 2002Principle of Marketing, $3^{\text {rd }}$ edition, Pretence Hall Europe.

Kotler, P \& Keller, K. L., 2006. Marketing Management (12th ed.). Upper Saddle River, NJ: Pearson Prentice Hall.

Minazzi, R., 2008. Customer satisfaction survey in the hospitality industry: comparison of international hotel chains questionnaires. Millano: Universita IULM. 
MintesnotBeyene, 2016. Governance and Public Service Delivery: The Case of Water Supply in AkakiKaliti SubCity. Master`s Degree Thesis. Addis Ababa University. Addis Ababa, Ethiopia.

Mohammed Hussen, 2008. Customer s` Satisfaction in Land Delivery Service by Urban Local Government: a case study of bishoftu town administration. Master`s Degree Thesis. Addis Ababa University. Addis Ababa, Ethiopia.

Nick Thijs and Patrick Staes, 2008. CUSTOMER SATISFACTION MANAGEMENT. European institute of Public Administration. Accessed on June, 2016

Parasuraman, A., Berry, L. L. and Zeithaml, V. A., 1985.A Conceptual-Model of ServiceQuality and Its Implications for Future-Research, Journal of Marketing, 49(4).

Parasuraman, A., Berry, L. L. and Zeithaml, V. A.,1985. A Conceptual-Model of ServiceQuality and Its Implications for Future-Research, Journal of Marketing, 49(4).

Parasuraman, A., Berry, L. L. and Zeithaml, V. A., 1988. SERVQUAL: A multiple-item scale form ensuring customer perceptions of service quality, Journal of Retailing, 64 (1).

Parasuraman, A., Berry, L. L. and Zeithaml, V. A., 1991. Refinement and reassessment of the

Parasuraman, A., Zeithaml, V. A., \& Berry, L. L., 1985. A conceptual model of service quality and its implications for future research, Journal of Marketing, 49, 41-50.

PaulosChanie, n.d. The challenges of the civil service reform in ethiopia: Initial observations.

PaulosChanie, n.d. The challenges of the civil service reform in ethiopia: Initial observations.

PrabhaRamseook, 2010. Service Quality In The Public Service. University of Technology, Mauritius. International journal of management and marketing research-Volume 3 - Number 1 - 2010. Accessed on June, 2016

RidaKhurshid, Dr. HummayounNaeem, Sana Ejaz, Faiza Mukhtar, TahaBatool, 2012. Service Quality and Customer Satisfaction in Publice Transport Sector of Pakistan : An Empirical Study. Master's degree thesis. Fatima Jinnah Women University, Rawalpindi, Pakistan. International journals of Economics and Management Science Vol. 1, No. 9,2012, pp. 24-30.

Robert V. Krejcie, Duluth Daryle W. Morgan, 1970. Determining Sample Size for Research Activities.Texas A. \& M. University: University of Minnesota.

Saunders, M., Lewis P. and Thornhill A., 2009. Research Methods for business students4th edition Pearson education limited

Saunders, M., Lewis P. and Thornhill A., 2009. Research Methods for business students4th edition Pearson education limited

Schiffman, G.L. and L.L. Kanuk, 2005. CustomerBehavior. Prentice-Hall of India Private Limited, New Delhi, pp: $14-15$.

Schiffman, G.L. and L.L. Kanuk, 2005. CustomerBehavior. Prentice-Hall of India Private Limited, New Delhi, pp: $14-15$.

Schmidt andStricklan, 2000.Client Satisfaction Surveying: Common Measurements Tool, Canadian Centre for Management Development November 2000.

SERVQUAL scale: a multiple-item scale for measuring customer permeations of service quality', Journal of Retailing, 67.

SERVQUAL scale: a multiple-item scale for measuring customer permeations of service quality', Journal of Retailing, 67.

Simon Gyasi Nimako and Foresight Kofi Azumah, 2009. An Assessment of Customer Satisfaction with Service Delivery of Mobile telecommunication Networks in Ghana. Master Thesis. Lulea University of Technology. ISSN:1653 - 0187

Spreng, R.A., and Mackoy, R.D.,1996. An Empirical Examination of a Model of Perceived Service Quality and Satisfaction. Journal of Retailing, 72 .

Spreng, R.A., Mackenzie, S.B. and Olshavsky, R.W.,1996. A Re-examination of the Determinant of Customer Satisfaction: Journal of Marketing.

Taati Rad, 2011. A Study of silent Customers, International Conference on Management (ICM) Proceeding, 790.

TamiratGezahgn, 2008. Measuring Level of Customer Satisfaction in Multimodal Transport Service. The Case of Ethiopian Shiping and Logistics Services Enterprise. Master`s Degree Thesis. Addis Ababa University. Addis Ababa, Ethiopia.

Tessa Bold, JakobSvensson, Bernard Gauthier, OttarMæstad and Waly Wane, 2011. Service Delivery Indicators: Pilot in Education and Health Care in Africa. Annual Report. Accessed on June, 2016

TibebeZeleke, 2012. Impact of service quality on customer satisfaction at the public owned National Alcohol and Liquor Factory. Master`s Degree Thesis. University of South Africa, South Africa.

Wilson, A., Zeithaml, V., Binter, M. and Gremler, D., 2008. Service Marketing: Integrating Customer Focus Across the Firm, McGraw-Hill, London.

Yonatan Gebre, 2010. Customers' Perception of Service Quality in Ethiopia banking sector: An Exploratory study. Master`s Degree Thesis. Addis Ababa University, Addis Ababa, Ethiopia. 
Yosef T., 2011. A Study of the Civil Service Reform in Adama city Administration: Regional State of Oromia, (MPA). Addis Ababa University: Addis Ababa.

Yuan Pei, 2013. Does Service Quality and Customer Satisfaction Effect Customer Loyalty? An Case Study of a Chinese Electric Appliance Chain Rerailer.Master's degree thesis. Accessed on June, 2016

ZerihunDuressa, 2014. Transformational leadership and its Applications in the public service organizations of Ethiopia.Vol.23, 2014, Addis Ababa.

ZerituFikre, 2010. Service delivery and customer satisfaction: (the Case of Ethiopian Electric Power Corporation Eastern Addis Ababa Region Customer Service Centers) .Master`s Degree Thesis. Addis Ababa University. Addis Ababa, Ethiopia. 